Cita: Soares, A.L.A.; Mendes, F.G.; Miguel, C.G.; Palheta, C.E.; Milan, F.J.; Collet, C.; Nascimento, J.V.; Carvalho, H.M. (2019). Variation in perceived collective efficacy among adolescent basketball players across 4-month competitive season. Cuadernos de Psicología del Deporte, Vol 19(1), 283-290

\title{
Variation in perceived collective efficacy among adolescent basketball players across 4-month competitive season.
}

\section{Variación en la eficacia colectiva percibida entre jugadores de baloncesto adolescentes a lo largo de una temporada competitiva de 4 meses.}

\section{Variação na eficácia coletiva percebida entre jogadores adolescentes de}

\section{basquetebol ao longo de uma temporada competitiva de 4 meses.}

\author{
Soares, André L. A. ${ }^{1}$, Mendes, Felipe G. ${ }^{1}$, Miguel, Caio G. ${ }^{1}$, Palheta, Carlos Ewerton ${ }^{1}$, Milan, Fabrício J. \\ ${ }^{1}$, Collet, Carine ${ }^{1,2}$, Nascimento, Juarez V. ${ }^{1}$, Carvalho, Humberto M. ${ }^{1}$ \\ ${ }^{1}$ Department of Physical Education, Federal University of Santa Catarina, Florianópolis, SC, Brazil; \\ ${ }^{2}$ College of Health Sciences and Sports, Santa Catarina State University, Brazil
}

\begin{abstract}
(150 words) (same order that title)
In sports, collective efficacy appears to be dependent on the interactions and organized dynamics between the players within the team. It is directly related to team's performance potential. This study examined the changes of perceived collective efficacy among young basketball players between 10 to 17 years across a 4-month competitive season, accounting for variation by age group. We explored the trends of perceived collective efficacy based on repeated measures across 4 months within the observed age range. Sixty-five adolescent male basketball players aged 13,7 (9,5 to 17,3) years at baseline were considered. Collective Efficacy Questionnaire for Sports (CEQS) was used to assess players' perception of collective efficacy. Players had high CEQS scores. Except for persistence, all CEQS factors did not vary by age group. No distinct trend of differences between age group was present. CEQS factors remained high on the second assessment, except for ability where there was a systematic decrease of the scores at end-season. A negative trend was apparent for persistence, preparation and unity as players were closer to late adolescence years. Overall, adolescent basketball players tend to have a positive perception of theirs and their teammates efficacy. Despite the small to trivial influence of exposure to training and competition during pubertal years observed, results suggest that approaching adult level may change negatively the efficacy perceptions of adolescent players. Hence, coaches and practitioners of youth basketball should consider that players' collective efficacy perceptions may vary as transient influences of pubertal growth and competitive level with age increase.
\end{abstract}

Keywords: Growth and Development; Youth; Athlete; Sports Psychology 


\section{Soares, André L. A., Mendes, Felipe G., Miguel, Caio G., Palheta, Carlos Ewerton, Milan, Fabrício J., Collet, Carine, Nascimento, Juarez V., Carvalho, Humberto M.}

\section{RESUMEN}

La eficacia colectiva en los deportes parece depender de las interacciones y dinámicas organizadas entre los jugadores del equipo. Está directamente relacionada con su potencial de rendimiento. Examinamos los cambios de eficacia colectiva percibidos entre jóvenes jugadores de baloncesto ( 10 a 17 años) por 4 meses de temporada competitiva, controlando la variación por grupo de edad. Exploramos las tendencias de eficacia colectiva percibida basados por medidas repetidas antes y después de 4 meses. Sesenta y cinco adolescentes jugadores de baloncesto, con 13,7 (9,5 a 17,3) años al inicio del estudio, fueron considerados. Se utilizó el Collective Efficacy Questionnaire for Sports (CEQS) para evaluar la percepción sobre la eficacia colectiva. Los jugadores tuvieron altas puntuaciones en el CEQS. Excepto por la persistencia, los factores del CEQS no variaron por grupo de edad. No hubo diferencias entre los grupos. Los factores del CEQS permanecieron altos en la segunda evaluación, excepto por la habilidad en que hubo una caída en los escores al final de la temporada. Una tendencia negativa fue aparente para la persistencia, preparación y unión en los años finales de la adolescencia. En general, los jugadores tienden a tener una percepción positiva de su eficacia y de sus colegas. A pesar de la influencia de la exposición al entrenamiento y la competición ser pequeña y no significativa durante la edad observada, los resultados sugieren que la aproximación del nivel adulto puede alterar negativamente las percepciones de eficacia de los jugadores. Se debe considerar que las percepciones de eficacia colectiva de los jugadores pueden variar como influencias transitorias del crecimiento pubertario y del nivel competitivo con el aumento de la edad.

Palabras clave Crecimiento y Desarrollo; Los jóvenes; Atleta; Psicología del Deporte.

\section{RESUMO}

A eficácia coletiva nos esportes parece depender das interações e dinâmicas organizadas entre os jogadores da equipe. Está diretamente relacionada ao seu potencial de desempenho. Examinamos as mudanças de eficácia coletiva percebida entre jovens jogadores de basquetebol (10 a 17 anos) ao longo de 4 meses de temporada competitiva, controlando a variação por faixa etária. Exploramos as tendências de eficácia coletiva percebida com base em medidas repetidas antes e depois de 4 meses. Sessenta e cinco adolescentes jogadores de basquetebol, com 13,7 (9,5 a 17,3) anos no início do estudo, foram considerados. O Collective Efficacy Questionnaire for Sports (CEQS) foi utilizado para avaliar a percepção sobre a eficácia coletiva. Os jogadores tiveram altas pontuações no CEQS. Exceto pela persistência, os fatores do CEQS não variaram por faixa etária. Não houveram diferenças entre as faixas etárias. Os fatores do CEQS permaneceram altos na segunda avaliação, exceto pela habilidade em que houve uma queda nos escores no final da temporada. Uma tendência negativa foi aparente para a persistência, preparação e união nos anos finais da adolescência. Em geral, os jogadores tenderam ter uma percepção positiva de sua eficácia e de seus colegas. Apesar da influência da exposição ao treinamento e competição ser pequena e não significativa durante a idade observada, os resultados sugerem que a aproximação do nível adulto pode alterar negativamente as percepções de eficácia dos jogadores. Devem-se considerar que as percepções de eficácia coletiva dos jogadores podem variar como influências transitórias do crescimento pubertário e do nível competitivo com o aumento da idade.

Palavras chave: Crescimento e Desenvolvimento; Jovens; Atleta; Psicologia do Esporte. 


\section{Collective efficacy responses to competition}

\section{INTRODUCTION}

Affective and social competencies are important for personal identity development of adolescents, and it is related to experiences in different environments and experiences during life (Palangana, 2015). Sport potentially provide positive experiences that favor youth development. In particular, young athletes' interactions with coaches, parents, and peers are important to promote a positive youth development, with potential benefits to a healthy and successful adult life (Camiré, Forneris, Trudel, \& Bernard, 2011; Gould \& Carson, 2008).

Team sports require the interaction individuals' performance, abilities, skills and competences, with athletes within the team sharing common goals. Additionally, interactions betweenathletes, with coaches, parents, peers and other people involved in a team context are relevant to develop and achieve optimal performance (Myers, Feltz, \& E. Short, 2004; Shearer, 2015).

A team shared belief in its capability to organize and execute some actions required to achieve given performance level is referred as collective efficacy (Bandura, 1997). It has been reported that collective efficacy is a significant predictor and directly related to team performance (Feltz \& Lirgg, 1998; Myers, Paiement, \& Feltz, 2007; Myers et al., 2004). Collective efficacy appears to be dependent on the interactions and organized dynamics between the players within the team, their competences, including physical competence, organization, structure and strategies. Athletes' perception about their own and their teammates competences and capacities may influence their development and achievement of higher levels of performance (Bandura, 1997). Hence, it appears that collective efficacy is highly relevant in the study of young athletes' development. Although there has been substantial attention to the study of collective efficacy in team sports, there has been limited data considering youth athletes.

In the present study we examined the changes of perceived collective efficacy among young basketball players and 10 to 17 years across a 4-month competitive season, accounting for variation by age group since youth sports are generally organized by competitive age groups. Based on the repeated measures across 4 months in the range of age observed, we explored the trends of perceived collective efficacy among young basketball players between 10 to 17 years.

\section{METHODS}

\section{Participants}

A pre-post design was used in this study. Sixty-five adolescent male basketball players aged 13,7 (9,5 to $17,3)$ years at baseline were considered. Players were engaged in a structured basketball training program of a club in metropolitan region of São Paulo (Mauá, São Paulo, Brazil) within under-11, under-13, under-15 and under-17 teams. They trained six to ten hours per week according to their age team competitive rules, yearly categorized such the state level competition supervised by the official basketball body in São Paulo, Brazil (Federação Paulista de Basketball). Note that the training context observed here was from an underserved region of São Paulo, hence the results will likely reflect those contexts. It is also important to consider that teams were classified by their position during championship season in different playing levels; those who were older were engaged in higher positions while youngers were in lower positions, what is expected they completed their games with teams in a similar level of performance.

Participants were informed about the procedures and nature of the study design, that their participation was voluntary, and they could leave the study at any time. All participants and their parents or legal guardians provided written consent. The study was approved by the institutional ethics committee.

\section{Procedures}

Players were assessed twice during the competitive season of each age category. First assessment occurred one week before the beginning of age category schedule (baseline) and second was four months later (follow-up) after the end of their competitive season. Questionnaires were filled before training sessions, at team's training facility.

Chronological age was calculated by subtracting birth date from date of each testing measure, to the nearest 0.1 year.

The Collective Efficacy Questionnaire for Sports (CEQS) (Short, Sullivan, \& Feltz, 2005) was developed and validated to examine the individuals' perception of collective efficacy levels. CEQS is 


\section{Soares, André L. A., Mendes, Felipe G., Miguel, Caio G., Palheta, Carlos Ewerton, Milan, Fabrício J., Collet, Carine, Nascimento, Juarez V., Carvalho, Humberto M.}

composed by a 5-factor, 20-item structure; these factors include Ability, Effort, Preparation, Persistence and Unity. In this study we used the Portuguese version of the CEQS (Paes, 2014). The Portuguese version is composed by 20 -items; all items were scored on a Likert scale from 1 (not all confident) to 10 (extremely confident). Its scale allows us to measure general score and by each factor. General score is composed by directly interrelated five factors: Ability, Effort, Preparation, Persistence and Unity. Ability represents athletes' belief about their capacity to do the needed tasks during a match or competition. Effort denotes athletes' beliefs to overcome adverse situations. Persistence is related to the overcoming during the match or game. Preparation reflects athletes' belief in their capacity to accomplish some fundamental and necessary tasks before the game or competition to achieve the team's best performance. Unity represents group's belief to solve problems and to maintain positive attitudes and effective communication (Paes, 2014; Short et al., 2005).

\section{Statistical Analysis}

We used Bayesian multilevel modeling to examine variation of perceived collective across the 4-month competitive season. Multilevel modelling, using Bayesian methods which treat parameters as random variables combining both sample data and prior distribution information to estimate posterior information (Gelman et al., 2013; McElreath, 2015), is a flexible and robust framework to deal with small scale applied team sport studies (Carvalho, Gonçalves, Grosgeorge, \& Paes, 2017). The hierarchical structure of repeated measures data considers observations (level-1) nested within each athlete (level-2), and in the present study we allowed for variation of players' CEQS responses across the 4-months competitive season to vary by age group (level-3). Hence, the multilevel model to describe each CEQS indicator response across the 4-months season included the time indicator (dummy variable coded 0 as pre-season and 1 , and 0 as end-season) as population level effects, and allowed to vary as group effects between players, and between players grouped by age group teams.

After explored variation across exposure to 4-months season, we aligned the repeated measures responses by chronological age (centered at grand mean age, 13,9 years) to describe the trends of perceived collective efficacy between the observed age range. We allowed for changes to vary between players at level-2.

We used weakly informative prior distributions for population-level, normal priors $(0$, $50)$, and for group-level effects, cauchy priors $(0,1)$, allowing model convergence, as well as ensuring that results reflect the knowledge available on the current data. We run four chains for 2,000 iterations with a warm-up length of 1,000 iterations. Models were implemented with Bayesian methods via Markov Chain Monte Carlo (MCMC) simulation, using Hamiltonian Monte Carlo and its extension, the No-UTurn Sampler using Stan (Stan Development Team, 2015). The interface with $S t a n$ was made in $R$ statistical language (R Core Team, 2015) using "brms" package (Bürkner, 2017).

\section{RESULTS}

Posterior means and uncertainty estimates pre- and end-season for CEQS scores are summarized in Table 1. Overall, the adolescent basketball players had high CEQS scores. The models in Table 1 also consider variation within players (level-1), between players (level-2) and between players grouped by age group team (level-3). Except for persistence, all factors CEQS did not vary by age group. However, no distinct trend of differences between age group was present as posterior means and $90 \%$ credible were as follows: under- $11,8,93$ (8,45 to 9,43$)$; under- $13,8,65$ (8,31 to $8,98)$; under- $15,8,18$ (7,74 to 8,61$)$; under- $17,9,01$ $(8,50$ to 9,54$)$. No substantial variation was observed for the changes in perceived CEQS between players, hence we report the results based on varying intercept models. Thus, there was substantial variation on CEQS responses between players, which remained about the same after exposure to the 4-months competitive season, irrespective of age group. The CEQS factors remained high after 4-months competitive season exposure, except for ability where there was a systematic decrease for players scores at end-season.

Changes in perceived collective efficacy of adolescent basketball players are summarized in Table 2. There was an apparent trend of decrease for persistence, preparation and unity with age. For both preparation and unity linear decreases did not vary between players (level-2), but for persistence there was group-level variation (between players) in changes across the age range. Both ability and effort 


\section{Collective efficacy responses to competition}

high values appeared to be stable as age increased. Also, there was no between players' variation on the rate of changes for ability and effort.

Table 1. Multilevel regression analysis of changes CEQS pre- and end-season in adolescent basketball players.

\begin{tabular}{|c|c|c|c|c|c|c|}
\hline & \multicolumn{3}{|c|}{ Population-level effects ( $90 \%$ credible interval) } & \multicolumn{3}{|c|}{ Group-level effects $(90 \%$ credible interval) } \\
\hline & Pre-season & End-season & $\begin{array}{c}\text { Changes across } \\
\text { the 4-months } \\
\text { season }\end{array}$ & $\begin{array}{c}\text { Level-1 } \\
\text { standard } \\
\text { deviation } \\
\end{array}$ & $\begin{array}{c}\text { Level-2 } \\
\text { standard } \\
\text { deviation }\end{array}$ & $\begin{array}{c}\text { Level-3 } \\
\text { standard } \\
\text { deviation }\end{array}$ \\
\hline \multicolumn{7}{|l|}{ Collective } \\
\hline \multicolumn{7}{|l|}{ Efficacy } \\
\hline Ability & $\begin{array}{c}8,60(8,36 \text { to } \\
8,83)\end{array}$ & $\begin{array}{c}8,31(8,06 \text { to } \\
8,55)\end{array}$ & $\begin{array}{c}-0,29(-0,54 \text { to }- \\
0,04)\end{array}$ & $\begin{array}{c}0,82(0,69 \text { to } \\
0,97)\end{array}$ & $\begin{array}{c}0,78(0,56 \text { to } \\
0,98)\end{array}$ & - \\
\hline Effort & $\begin{array}{c}8,93(8,71 \text { to } \\
9,15)\end{array}$ & $\begin{array}{c}8,84(8,61 \text { to } \\
9,07)\end{array}$ & $\begin{array}{c}-0,09(-0,35 \text { to } \\
0,17)\end{array}$ & $\begin{array}{c}0,83(0,70 \text { to } \\
1,00)\end{array}$ & $\begin{array}{c}0,70(0,47 \text { to } \\
0,91)\end{array}$ & - \\
\hline Persistence & $\begin{array}{c}8,69(8,13 \text { to } \\
9,30)\end{array}$ & $\begin{array}{c}8,57(7,99 \text { to } \\
9,20)\end{array}$ & $\begin{array}{c}-0,13(-0,44 \text { to } \\
0,19)\end{array}$ & $\begin{array}{c}1,03(0,86 \text { to } \\
1,22)\end{array}$ & $\begin{array}{c}0,62(0,23 \text { to } \\
0,92)\end{array}$ & $\begin{array}{c}0,61(0,16 \text { to } \\
1,37)\end{array}$ \\
\hline Preparation & $\begin{array}{c}8,80(8,60 \text { to } \\
9,01)\end{array}$ & $\begin{array}{c}8,69(8,46 \text { to } \\
8,92)\end{array}$ & $\begin{array}{c}-0,11(0,37 \text { to }- \\
0,17)\end{array}$ & $\begin{array}{c}0,89(0,75 \text { to } \\
1,05)\end{array}$ & $\begin{array}{c}0,48(0,14 \text { to } \\
0,74\end{array}$ & - \\
\hline Unity & $\begin{array}{c}8,62(8,35 \text { to } \\
8,89)\end{array}$ & $\begin{array}{c}8,66(9,43 \text { to } \\
7,88)\end{array}$ & $\begin{array}{c}0,00(-0,27 \text { to } \\
0,28)\end{array}$ & $\begin{array}{c}0,91(0,77 \text { to } \\
1,07)\end{array}$ & $\begin{array}{c}0,93(0,71 \text { to } \\
1,16)\end{array}$ & - \\
\hline
\end{tabular}

Table 2. Changes in perceived collective efficacy of Brazilian adolescent players from 10 to 17 years (age centered at 13,86 years in the models).

Collective efficacy

\begin{tabular}{|c|c|c|c|c|c|}
\hline & Ability & Effort & Persistence & Preparation & Unity \\
\hline \multicolumn{6}{|c|}{ Population-level effects ( $90 \%$ credible interval) } \\
\hline Intercept & $\begin{array}{c}8,46(8,26 \text { to } \\
8,65)\end{array}$ & $\begin{array}{c}8,89(8,70 \text { to } \\
9,07)\end{array}$ & $\begin{array}{c}8,51(8,29 \text { to } \\
8,73)\end{array}$ & $8,74(8,58$ to 8,90$)$ & $\begin{array}{c}8,61(8,39 \text { to } \\
8,83)\end{array}$ \\
\hline Age centered & $\begin{array}{c}-0,08(-0,19 \text { to } \\
0,04)\end{array}$ & $\begin{array}{c}-0,07(-0,18 \text { to } \\
0,04)\end{array}$ & $\begin{array}{c}-0,13(-0,29 \text { to } \\
0,01)\end{array}$ & $\begin{array}{c}-0,13(-0,22 \text { to }- \\
0,03)\end{array}$ & $\begin{array}{c}-0,13(-0,26 \text { to } \\
0,01)\end{array}$ \\
\hline \multicolumn{6}{|c|}{ Group-level effects (90\% credible interval) } \\
\hline Level 1 standard deviation & $\begin{array}{c}0,86(0,72 \text { to } \\
1,02)\end{array}$ & $\begin{array}{c}0,84(0,70 \text { to } \\
1,00)\end{array}$ & $\begin{array}{c}1,02(0,85 \text { to } \\
1,23)\end{array}$ & $0,91(0,77$ to 1,05$)$ & $\begin{array}{c}0,91(0,77 \text { to } \\
1,07)\end{array}$ \\
\hline \multicolumn{6}{|l|}{ Level 2} \\
\hline Intercept & $\begin{array}{c}0,72(0,47 \text { to } \\
0,96)\end{array}$ & $\begin{array}{c}0,66(0,40 \text { to } \\
0,89)\end{array}$ & $\begin{array}{c}0,57(0,22 \text { to } \\
0,89)\end{array}$ & $0,38(0,06$ to 0,66$)$ & $\begin{array}{c}0,89(0,65 \text { to } \\
1,13)\end{array}$ \\
\hline Age centered & - & - & $\begin{array}{c}0,25(0,06 \text { to } \\
0,46)\end{array}$ & - & \\
\hline
\end{tabular}

\section{DISCUSSION}

The present study examined variation in collective efficacy in adolescent basketball players between the beginning and the end of a 4-month competitive season. Also, we examined the trend of changes in perceived collective efficacy between 10 and 17 years among the Brazilian basketball players. Overall, the perceived collective efficacy of the adolescent basketball was high and without much variation after exposure to a competitive period exposure, mostly independent of age group. Only ability scores decreased after the competitive season. These observations suggest that the adolescent basketball players had a positive perception of their individual and team's capacity to organize and accomplish tasks. 


\section{Soares, André L. A., Mendes, Felipe G., Miguel, Caio G., Palheta, Carlos Ewerton, Milan, Fabrício J., Collet, Carine, Nascimento, Juarez V., Carvalho, Humberto M.}

A negative trend of change was apparent for persistence, preparation and unity as players were closer to late adolescence years.

No substantial variation by age group was observed in the scores of perceived collective efficacy, with exception of persistence, where no gradient of differences where observed by age group team. The results suggest that adolescent players had positive perceptions about mutual trust and respect, commitment to one another and to the task at hand (Hampson \& Jowett, 2014). It has been noted that shared confidence and trustful can help improving interindividual relationships, and lead athletes to achieve higher levels of performance, leading them to be succeeded (Fransen, Mertens, Feltz, \& Boen, 2017; Martínez-Santos \& Ciruelos, 2013; Myers et al., 2004). However, it appears that at least for persistence, there may be variation that may be accounted to the training environment (in the present study players and club are from an underserved part of São Paulo metropolitan region), given the observed variation by age group, meriting further study.

Psychological healthiness is directly related to athletes development, and youth sports may be favorable to a positive youth development purpose with a supportive and positive environment of teaching, learning, playing and competition (Côté \& Hancock, 2016; Fraser-Thomas, Côté, \& Deakin, 2005; Strachan, Côté, \& Deakin, 2009). It is important that all these factors are aligned with the same purpose and to be positive to youth development, especially in underserved contexts (Reverdito et al., 2017).

The adolescent basketball players showed a trend of homogenous responses of collective efficacy across the competitive 4-month season. These results were present both considering within players and between players and age category teams. These observations are consistent with available data with adult team sports (Feltz \& Lirgg, 1998; Myers et al., 2004; Watson, Chemers, \& Preiser, 2001). Despite substantial between individual maturity-associated variation in size and performance typical among adolescent basketball players (Carvalho, Goncalves, Collins, \& Paes, 2018), which is reasonable to assume in the present sample, the results support collective efficacy as a shared belief that is mediated by team level influences including group size, past team performance, and confident leadership in the creation, maintenance, and enhancement of collective efficacy (Watson et al., 2001).
Growth-related changes happen through childhood and adolescence in physical and physiological dimensions (Carvalho et al., 2018). It is likely to similar growth related changes in psychological (i.e. assets of development, sources of enjoyment, motivation, self-efficacy and others) (de Bruin, Rikers, \& Schmidt, 2007; de Bruin, Smits, Rikers, \& Schmidt, 2008; Gonçalves, Silva, Carvalho, \& Gonçalves, 2011; Santos, Carvalho, \& Gonçalves, 2018). To our best knowledge, this is the first report to examine changes in perceived collective efficacy in young athletes, particularly basketball players. In the present study we observed a negative trend of change for perceived persistence, preparation and unity, and a stability in perceived ability and effort. The negative trend of changes observed may be mostly due to contextual effects. We may suppose that specific competitive context of each team may contribute to explain the negative trend for persistence, preparation and unity, where the younger teams were having more competitive success than the older teams in their respective competition during the observation. On the other hand, it may also contribute to the results the fact that in the observed club under 17 was the last competitive team of the youth program and players may perceive potential difficulties to continue engaged in organized basketball after 17 years.

Caution is warranted in the interpretations and generalization of our observation. First, it is likely that interaction between players' variability in pubertal development, accumulated training experience and functional performance may influence adolescent players' perceptions. This was not possible to accounted in this study. Also, our results suggest a potential influence of the context of practice. Hence different training contexts, coaching support or levels of competition may provide contrasting observations.

\section{PRACTICAL APPLICATIONS}

In summary, variation in collective efficacy in adolescent basketball players between the beginning and the end of a 4-month competitive season was spurious at best. Also, when examining the trend of changes in perceived collective efficacy between 10 and 17 years it was apparent a negative trend of perceived collective efficacy, in particular persistence, preparation and unity with age. Overall, adolescent basketball players tend to have a positive perception of theirs and their teammates collective efficacy. 


\section{Collective efficacy responses to competition}

Despite the small to trivial influence of exposure to training and competition during pubertal years observed, the results suggest that approaching adult level may change negatively the efficacy perceptions of the adolescent players. Youth basketball coaches should be aware that adolescent players' collective efficacy perceptions may vary as transient influences of pubertal growth and competitive level with age increase. Hence the present study highlights the need to include psychological and behavioral characteristics to help players to appropriately understand their performance development and expectations.

\section{REFERENCES}

1. Bandura, A. (1997). Self-efficacy : the exercise of control.

2. Bürkner, P.-C. (2017). brms: An R Package for Bayesian Multilevel Models using Stan. Journal of Statistical Software, 80, 1-28.

3. Camiré, M., Forneris, T., Trudel, P., \& Bernard, D. (2011). Strategies for Helping Coaches Facilitate Positive Youth Development Through Sport. Journal of Sport Psychology in Action, 2(2), 92-99. doi: 10.1080/21520704.2011.584246

4. Carvalho, H. M., Goncalves, C. E., Collins, D., \& Paes, R. R. (2018). Growth, functional capacities and motivation for achievement and competitiveness in youth basketball: an interdisciplinary approach. $J$ Sports Sci, 36(7), 742-748. doi: 10.1080/02640414.2017.1340654

5. Carvalho, H. M., Gonçalves, C. E., Grosgeorge, B., \& Paes, R. R. (2017). Validity and usefulness of the Line Drill test for adolescent basketball players: a Bayesian multilevel analysis. Res Sports Med, 25(3), 333-344.

doi: 10.1080/15438627.2017.1314296

6. Côté, J., \& Hancock, D. J. (2016). Evidencebased policies for youth sport programmes. International Journal of Sport Policy and Politics, $\quad 8(1), \quad 51-65 . \quad$ doi: 10.1080/19406940.2014.919338
7. de Bruin, A. B., Rikers, R. M., \& Schmidt, H. G. (2007). The influence of achievement motivation and chess-specific motivation on deliberate practice. J Sport Exerc Psychol, 29(5), 561-583.

8. de Bruin, A. B., Smits, N., Rikers, R. M., \& Schmidt, H. G. (2008). Deliberate practice predicts performance over time in adolescent chess players and drop-outs: a linear mixed models analysis. Br J Psychol, 99(Pt 4), 473497. doi: 10.1348/000712608X295631

9. Feltz, D., \& Lirgg, C. (1998). Perceived team \& player efficacy in hockey (Vol. 83).

10. Feltz, D. L., \& Lirgg, C. D. (1998). Perceived team and player efficacy in hockey. $J$ Appl Psychol, 83(4), 557-564.

11. Fransen, K., Mertens, N., Feltz, D. L., \& Boen, F. (2017). "Yes, we can!" review on team confidence in sports. Curr Opin Psychol, 16, 98-103. doi: 10.1016/j.copsyc. 2017.04.024

12. Fraser-Thomas, J., Côté, J., \& Deakin, J. (2005). Youth sport programs: An avenue to foster positive youth development (Vol. 10).

13. Gelman, A., Carlin, J. B., Stern, H. S., Dunson, D. B., Vehtari, A., \& Rubin, D. B. (2013). Bayesian Data Analysis, Third Edition. Boca Raton, FL: Chapman \& Hall/CRC Press.

14. Gonçalves, C. E., Silva, M., Carvalho, H. M., \& Gonçalves, A. (2011). Why do they engage in such hard programs? The search for excellence in youth basketball. $J$ Sports $S c i$ Med, 10(3), 458-464.

15. Gould, D., \& Carson, S. (2008). Life skills development through sport: current status and future directions. International Review of Sport and Exercise Psychology, 1(1), 58-78. doi: 10.1080/17509840701834573

16. Hampson, R., \& Jowett, S. (2014). Effects of coach leadership and coach-athlete relationship on collective efficacy. Scand $J$ Med Sci Sports, 24(2), 454-460. doi: 10.1111/j.1600-0838.2012.01527.x

17. Harriss, D., \& Atkinson, G. (2009). International Journal of Sports Medicine - 


\section{Soares, André L. A., Mendes, Felipe G., Miguel, Caio G., Palheta, Carlos Ewerton, Milan, Fabrício J., Collet, Carine, Nascimento, Juarez V., Carvalho, Humberto M.}

Ethical Standards in Sport and Exercise Science Research (Vol. 30).

18. Martínez-Santos, R., \& Ciruelos, O. (2013). Collective efficacy, cohesion and performance in Spanish amateur female basketball (Vol. 22).

19. McElreath, R. (2015). Statistical rethinking : a Bayesian course with examples in $R$ and Stan. Boca Raton, FL: Chapman \& Hall/CRC Press.

20. Myers, N., A. Paiement, C., \& Feltz, D. (2007). Regressing Team Performance on Collective Efficacy: Considerations of Temporal Proximity and Concordance (Vol. 11).

21. Myers, N., Feltz, D., \& E. Short, S. (2004). Collective Efficacy and Team Performance: A Longitudinal Study of Collegiate Football Teams (Vol. 8).

22. Paes, M. J. (2014). Validação do Collective Efficacy Questionnaire for Sports (CEQS) para atletas brasileiros. (Dissertação (mestrado) - Universidade Federal do Paraná, Setor de Ciências Biológicas, Programa de Pós-Graduação em Educação Física. Defesa: Curitiba, 28/03/2014), Universidade Federal do Paraná, http://hdl.handle.net/1884/36012.

23. Palangana, I. C. (2015). Desenvolvimento e aprendizagem em Piaget e Vygotsky: a relevância do social. Sammus Editorial.

24. R Core Team. (2015). R: A Language and Environment for Statistical Computing Retrieved from http://www.R-project.org/

25. Reverdito, R., Galatti, L., Carvalho, H., Scaglia, A., Côté, J., Gonçalves, C., \& R. Paes, R. (2017). Developmental Benefits of Extracurricular Sports Participation Among Brazilian Youth (Vol. 124).

26. Santos, A. J., Carvalho, H. M., \& Gonçalves, C. E. (2018). Personal and ecological factors in school sport : a multilevel approach. South African Journal for Research in Sport, Physical Education and Recreation, 40(1), 125-140.

27. Shearer, D. A. (2015). Collective efficacy at the Rugby World Cup 2015 - The role of imagery and observation. European Journal of Sport Science, 15(6), 530-535. doi: 10.1080/17461391.2015.1034787

28. Short, S. E., Sullivan, P., \& Feltz, D. L. (2005). Development and Preliminary Validation of the Collective Efficacy Questionnaire for Sports. Measurement in Physical Education and Exercise Science, 9(3), 181-202. doi: $10.1207 / \mathrm{s} 15327841 \mathrm{mpee} 0903 \_3$

29. Stan Development Team. (2015). Stan: $A$ $C++$ Library for Probability and Sampling Retrieved from http://mc-stan.org/

30. Strachan, L., Côté, J., \& Deakin, J. (2009). An Evaluation of Personal and Contextual Factors in Competitive Youth Sport (Vol. 21).

31. Watson, C. B., Chemers, M. M., \& Preiser, N. (2001). Collective Efficacy: A Multilevel Analysis. Personality and Social Psychology Bulletin, 27(8), 1057-1068. doi: $10.1177 / 0146167201278012$ 